\title{
The first Tunisian fuel cell test station
}

\author{
M. Barbouche ${ }^{1}$, F. krout ${ }^{1}$, M. chiha ${ }^{1}$, K. charradi1, A. Zakarya ${ }^{1}$ and R. chtourou ${ }^{1}$ \\ 1. Photovoltaic Laboratory, Centre for Research and Energy Technologies CRTEn, BP 95, Hammam Lif \\ 2050, Tunisia, \\ E-mail: barbouchemed@gmail.com,fehry_krout@yahoo.fr, charradi_kaled2000@yahoo.fr, \\ zakarya_ahmed78@yahoo.fr, radhouane.chtourou@inrst.rnrt.tn
}

\begin{abstract}
Great efforts are presently being undertaken to develop fuel cell applications. In this study, a design and realization of a fuel cell test station is described. The control of the stack temperature and the optimization of some parameters, such as the acquisition and equilibrium time for each value of the current density are necessary steps for an objective and trustworthy comparison of the performance data. Our test bench comprises two major parts hardware and software.
\end{abstract}

The hardware part comprises an electrical cabinet, a power supply, an acquisition chain, an electronic load, mass flow controllers, temperature controller, solenoid valves, and solid state relay. The assemblies of the different parts of the test station are made considering our project objectives, such as, security, size (Length: $1000 \mathrm{~mm}$, Width: $800 \mathrm{~mm}$, Height: $1900 \mathrm{~mm})$, accessibility and mobility...etc. The software part includes not only the development of the pipelines and instrumentations diagrams but also the design of the rack using solid-works software. An interface was developed in the LABVIEW environment to enable mass flow controller and the solenoid valves control. It also allows the automatic data acquisition (fuel cell power, temperature and pressure).

Preliminary measurements are made with a PEMFC $(25 \mathrm{~cm} 2)$ to make out the effect of temperature, relative humidity, back pressure and in the end the effect of cell number on the fuel cells power. The results may be used to find the best operating conditions.

Keywords: Test station, Labview, Fuel cell, Virtual Instrumentation, polarization curve.

\section{INTRODUCTION}

Great efforts are presently being undertaken to develop fuel cell applications. Fuel cells are electrochemical devices that produce electricity at high efficiency without combustion. Fuel cells are emerging as viable candidates as power sources in many applications. An intensive experimental work is necessary for investigating the performance of a fuel cell, like pressure, cell's temperature, humidity condition and mass flow rates. A laboratory must have the potential to examine and to visualize different steps of preparation of Fuel Cell. The progress in digital technology and computerassisted design grant incontestable benefits in several fields, especially in measurement and thus, gave rise to a new concept in instrumentation technology which is called virtual instrumentation [1]. Fuel cell test station is developed and built in order to evaluate, optimize, and qualify our fuel cell. The measurement station consists of two major parts hardware and software. This station allows measurement and recording of all relevant data (cell voltages, current, temperatures and gas flow). Current-voltage characteristics have to be recorded under quasi-stable conditions. This allows making statements about the performance of fuel cells [2]. Security measures are taking into account when designing the test station to ensure maximum safety. The aim of this work is to present ETRERA's efforts in the construction of a simple, efficient and cheap fuel cell test station, its implementation and optimization. This paper will be useful for groups that already work in the fuel cell field.

\section{REQUIREMENTS OF THE TEST STATION}

It is important to be able to accomplish analyses under always the same conditions and parameters to ensure sufficiently large reproducibility. Parameters 
must then be kept in very small intervals. It is necessary to acquire and to store data for a later evaluation and to compare different results. Measured values are to be saved in a given time interval.

All parameters must be supervised to minimize manipulation errors.

A good continuity in planning and construction of the equipment must be provided for a possible extension in the future. It means that old and new constructions units have to be compatible.

\section{HYDRO-MECHANICAL DESIGN}

\section{A. Design of the rack}

The different parts of the fuel cell test station are mounted on a metal rack system to facilitate the measurement spots. The design of this rack was performed using the Solidworks software (fig 1,2). Congestion and location of different pieces inside the rack (humidifiers, pipelines, electronic components, etc.) are considered in the design in order to minimize the size of rack and to reduce its cost while ensuring the proper functioning of station.

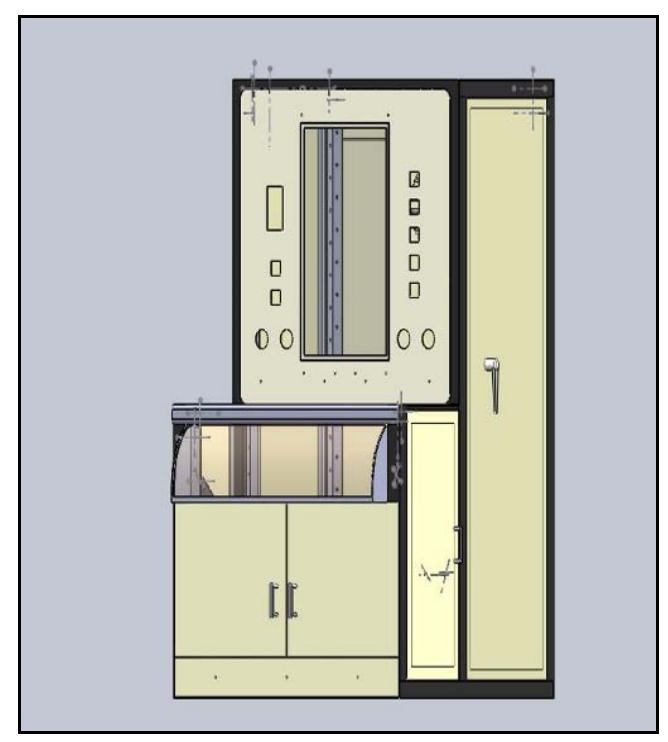

Fig. 1. 3-dimensional view of the rack

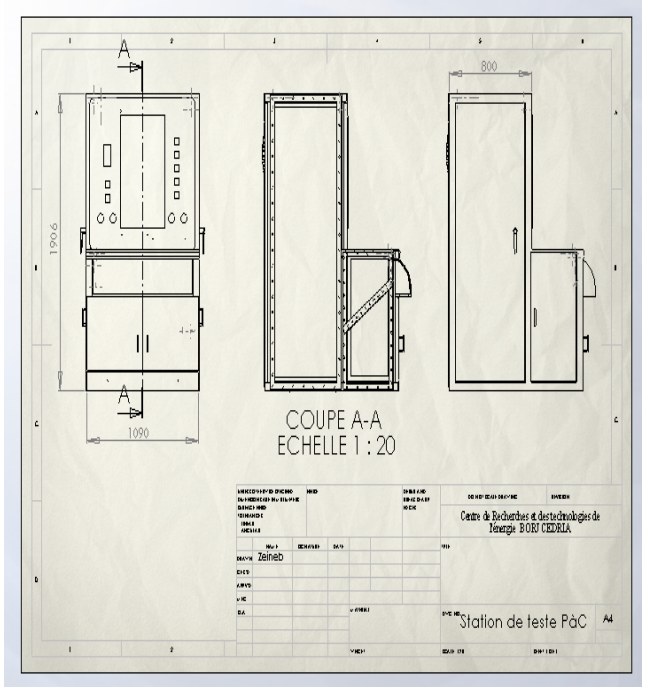

Fig. 2. Different views of the Rack

\section{B. Diagram of gas design}

Diagram of gas (fig 3) consists of solenoids to allow or to interrupt gas circulation, mass flow controllers (MFC) to control gas flow, one-way valves for safety reasons, humidifiers to increase the moisture percentage in air in order to facilitate the chemical reaction, manual valves and filters. The feed gas flows are controlled by four MFCs at low and high level for each of hydrogen and air streams. It's also possible to use dry mode by using three way valves and bypassing the humidifiers. Piping lines used to connect each part of the system are made of steel. Air and hydrogen are entering fuel cell through two separate heated lines to minimize condensation in gas streams. For safety purpose, a N2 purge system was considered for anode and cathode circuit.

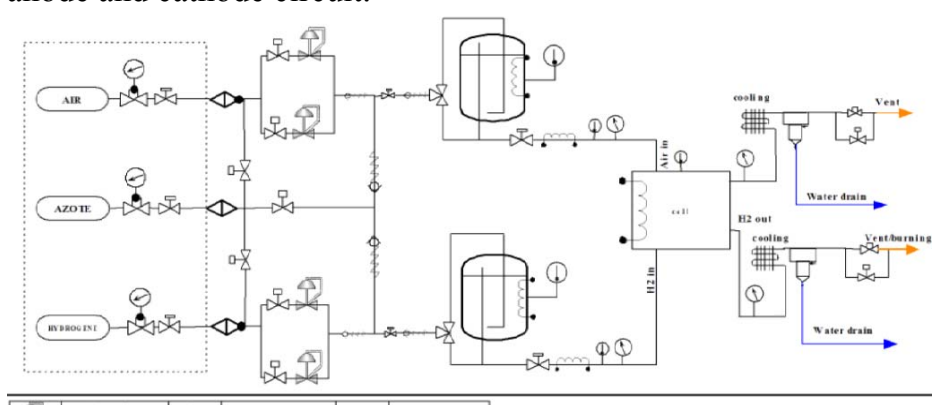

\section{Design and construction of humidifiers}

The Humidifiers (fig 4) are designed to power the fuel cell test station with humidified gases. Two humidifiers are available, one for $\mathrm{H}_{2}$ and the other for air. This device consists of a 316L stainless steel bottle, gas and water inlets, a gas outlet moistened a 
system for measuring the water level in the bottle, a temperature sensor and a heating bottle system.

For each humidifier, heating is provided with a heating element. The use of heat insulator allows us to have a thermal protection of bottle which increases the heat exchange with the water. Water's temperature is regulated by PID temperature controller. Security alarms are switched on when exceeding the maximum operating temperature of the resistance. A judgment of system is performed by a thermostat.

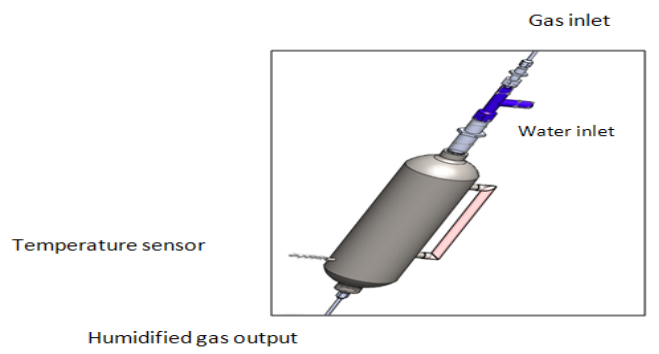

Fig. 4. Design of the humidifier

In this manner, it is possible to determine the dependence of the power generation on the humidification degree of hydrogen and to optimally control the humidity.

\section{Anode and cathode supply}

\section{1) Cathode supply}

The supply of gas to the cathode can be done alternatively by air in normal operation or nitrogen (used directly from commercial cylinders) in case of purge. The switching of the supply gas is done automatically using solenoid valves. A mass flow controller provides a constant and controllable gas flow. The gas can be passed through a heated container filled with water. Humidity control is done by controlling the temperature in the humidifier.

\section{2) Anode supply}

The supply of the anode is done with hydrogen, this happens according to the same principle as the cathode supply. In fact, the gas supply to the anode can be done alternatively by hydrogen in normal operation or nitrogen in case of purge. A constant gas flow which can be humidified is adjusted by a mass flow controller.

It's necessary that the tube between the fuel cell and the humidifier is well insulated to prevent a condensation of the water because of a cooling of the hydrogen on the way to the stack. In addition, two heaters are set up before the gas entry in the stack to adjust operating temperature.

\section{TEST STATION EQUIPMENT SPECIFICATIONS}

The hardware of fuel cell test station shall meet the minimum requirements specified in Table 1.

TABLE I. Fuel Cell Test Station Specifications

\begin{tabular}{|c|c|}
\hline Description & Specification \\
\hline \multicolumn{2}{|l|}{ Gas Supply } \\
\hline $\begin{array}{l}\text { Anode Gas Supply: Hydrogen Mass Flow } \\
\text { Controller }\end{array}$ & $\begin{array}{l}\text { Minimum Flow Range: } 0 \text { to } 10 \mathrm{~L} / \mathrm{min} \\
\text { Accuracy } \pm 3 \% \text { Rate }\end{array}$ \\
\hline $\begin{array}{l}\text { Cathode Gas Supply: Air Mass Flow } \\
\text { Controller }\end{array}$ & $\begin{array}{l}\text { Minimum Flow Range: } 0 \text { to } 20 \mathrm{~L} \text { min } \\
\text { Accuracy } \pm 3 \% \text { Rate }\end{array}$ \\
\hline Nitrogen Purge for A node and Cathode & Nitrogen: 0 to $10 \mathrm{~L} / \mathrm{min}$ \\
\hline \multicolumn{2}{|l|}{ Humidification } \\
\hline Humidification System & $\begin{array}{l}\text { Dew point Range: } 30^{\circ} \mathrm{C} \text { to } 80^{\circ} \mathrm{C} \\
\text { Accuracy: } \pm 1^{\circ} \mathrm{C} \text { at } 1.2 \text { bar } \\
\text { Dew point control: } \pm 5^{\circ} \mathrm{C} \text { stability } \\
\text { Anode: } 0.7 \mathrm{~L} \text { min } \mathrm{H} 2 \text { flow, saturated at }(1.2 \\
\left.\text { bar }-80^{\circ} \mathrm{C}\right) \\
\text { Cathode: } 2.5 \mathrm{~L} / \text { min Air flow, saturated at } \\
\left(1.2 \text { bar }-80^{\circ} \mathrm{C}\right)\end{array}$ \\
\hline $\begin{array}{l}\text { Stack/Cell T emperature Control System } \\
\text { Cell endplate heaters with PID heating } \\
\text { control }\end{array}$ & $\begin{array}{l}\text { Temp Control Range: } 30 \text { to } 95^{\circ} \mathrm{C} \\
\text { System Control: }+/-2^{\circ} \mathrm{C}\end{array}$ \\
\hline \multicolumn{2}{|l|}{ E lectrical/Software Service/F ea ture } \\
\hline Load B ank & $\begin{array}{l}0 \text { - } 60 \text { Amps } \\
\text { Accuracy: } \pm 1 \% \text { of reading } \\
\text { Lowest voltage: } 0.1 \mathrm{~V} \\
\text { Re sponse time: }=1 \text { second } \\
\text { Control: Constant Current and Constant } \\
\text { Voltage }\end{array}$ \\
\hline Cell Voltage Monitor & Accuracy: $\pm 2 \mathrm{mV}$ or better \\
\hline
\end{tabular}

\section{DATA ACQUISITION AND SYSTEM CONTROL}

\section{A. Control of solenoid valve and MFC by computer}

For many test benches of this kind, the control of the plant is done by a classical programmable logic controller (PLC), after numerous measurements and tests were carried out, it could be noted that the process power of the PLC is limited considering the improvement of dynamic behavior of a fuel cell system and taking over extensive calculation tasks [3]. Therefore, an interface is developed with LabVIEW software (fig 5) for the superordinate PC-based measurement and system control in order to vary specific parameters. The opening and closing of valves are controlled by the computer and the flow set point for the mass flow controller is also issued from the computer using the same interface. Defects can be limited and the development time can be shortened by using proven Labview software tools. 


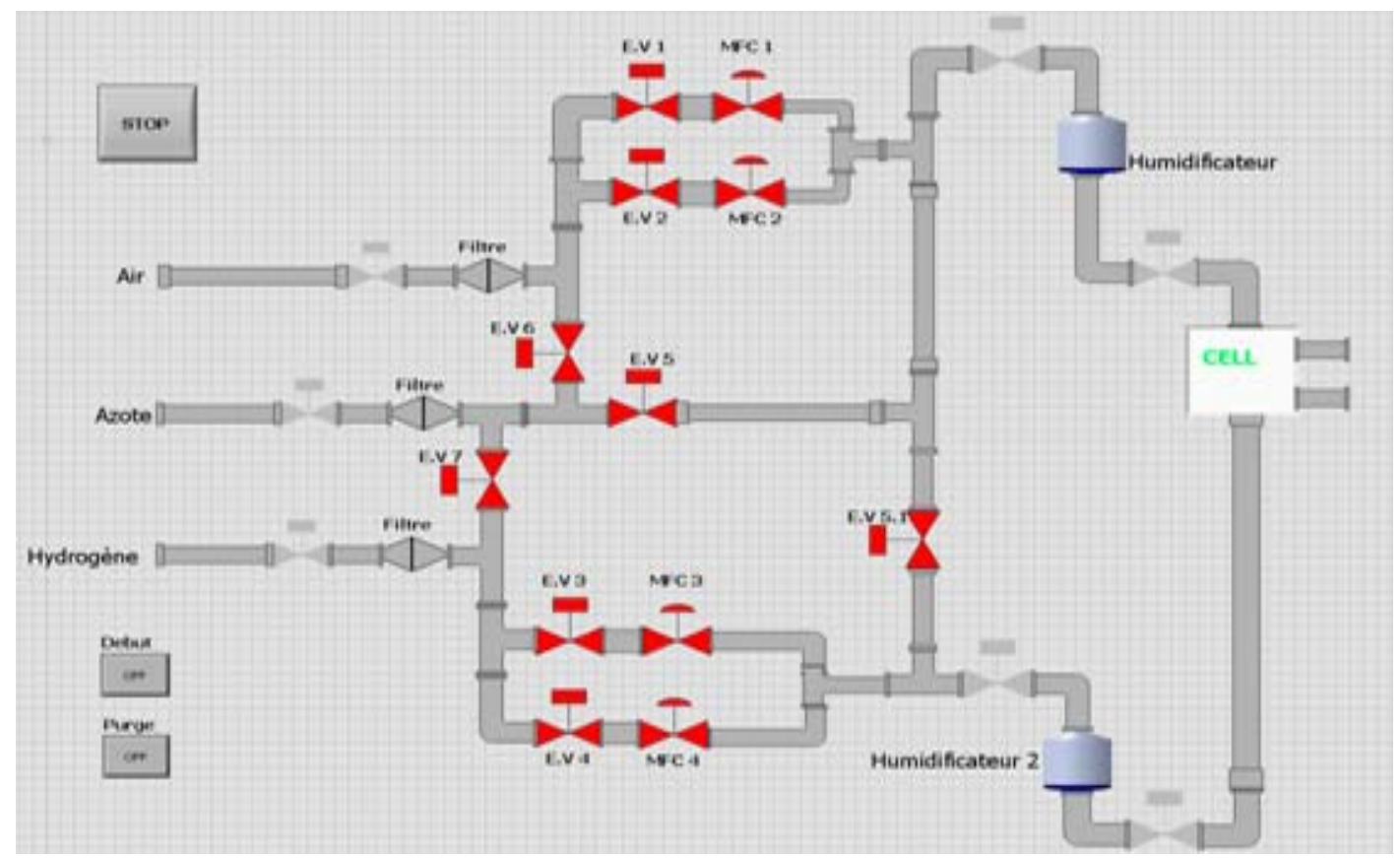

Fig. 5. Control of electro valves and MFC

\section{B. Electrical components}

For adjusting the electrical load of the cell and for the measurement of current-voltage characteristics, an electronic load is placed in series with generator to avoid the current of short circuit. The instrument used in the test station described can work at constant voltage ( $\mathrm{CV}$, Potentiostatic mode) or constant current ( $\mathrm{CC}$, Galvanostatic mode), the measurements were carried out under CC mode. All the measurements are collected using MODBUS and 488.2 standard protocols; therefore we have full supervision and control of the devices.

\section{Visualization/data acquisition}

At the test station, visualization is necessary to display momentary measured values and to observe the process (Fig. 6). The histogram makes it possible to interpret the trends. The interface provides a menu control working with simple icons. So the operation can be significantly improved.

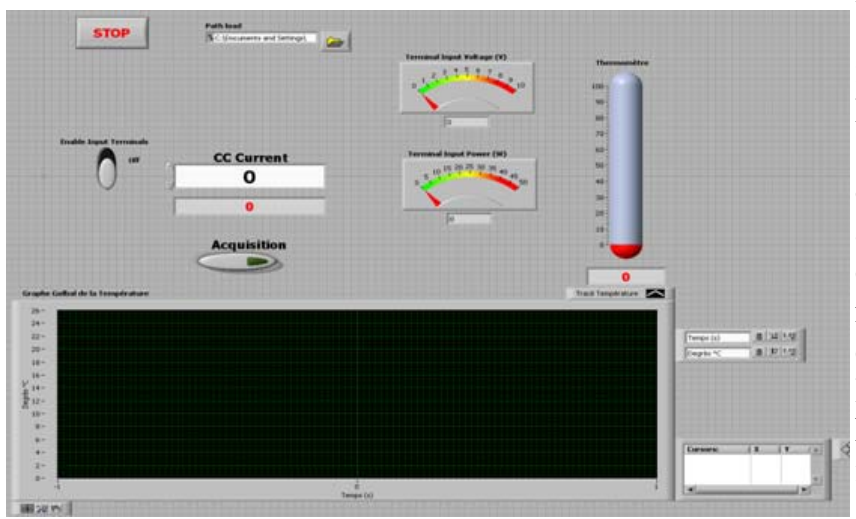

Fig. 6. Design of acquisition interface
The following values are shown:

- Temperatures (cell, media supply, humidifier etc.);

- Cell current;

- Cell voltage;

- Cell power;

- Pressures (media supply, humidifier, tank etc.);

\section{Safety system}

Security measures are taken into account. All temperatures in the system are supervised. The test bench is turned off automatically at a temperature overrun to avoid an overheating of the system. A gas leak sensor is set up to detect leakage of hydrogen.

\section{E. Results and operation of the Fuel Cells}

In order to test the different instruments, we have started our experimental studies with commercial fuel cell (Fig. 7) that has been provided by Nantes Polytechnic group which is used in their laboratory [4]. The used fuel cell is formed by the association of several single cells. The anode plate is formed by an porous material for hydrogen diffusion. The cathode is supplied with compressed air. The membrane is made of Gore select. For this kind of cell, we have adopted 'Hydrogen Blocked Mode'. In fact, two mass-flows were used to control the hydrogen and air flows. Various measures are then implemented. 


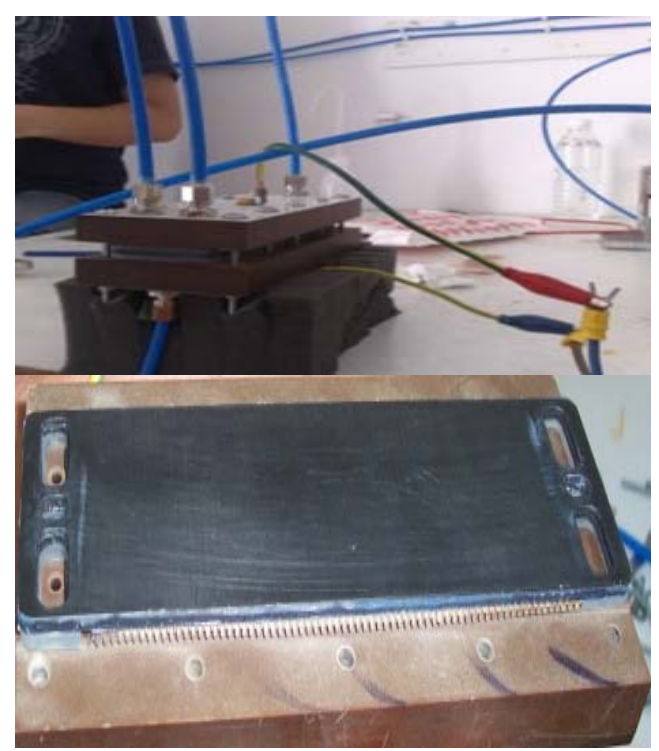

Fig. 7. Commercial fuel cell

The characteristics of the stack are determined from the polarization curve and power depending on the current density (fig 8). These tests will determine:

- The electrical characteristics of the cell;

- The resistance of the MEA;

- The membrane permeability to hydrogen.

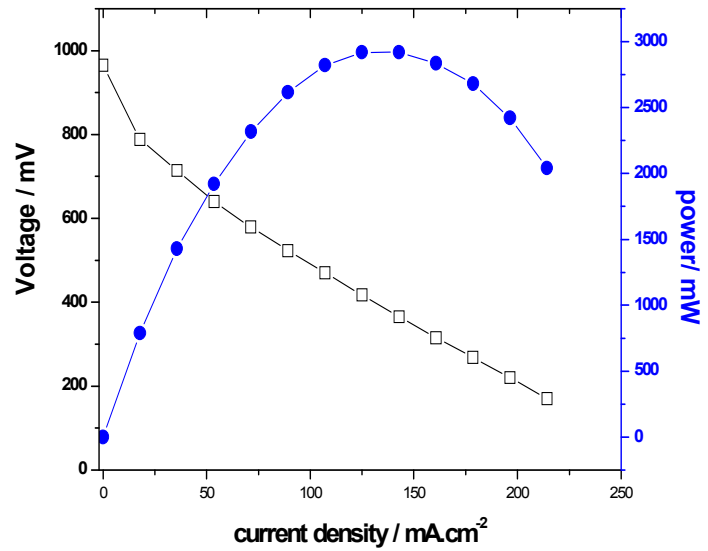

Fig 8 . Evolution of voltage and power vs. current density charged by the battery (a single cell)

From $V=f(I)$, curve can be divided into two regions:

- For low current density, the activation polarization loss is dominant. At this point, electronic barriers must be overcome prior to current and ion flow.

Activation losses increase as current increases.

Activation polarization is directly related to the rates of electrochemical reactions.

- For the current density is average, the ohmic losses, which are directly proportional to current density, are prevailing. At this point, ohmic polarization (loss) varies directly with current, increasing over the entire range of current because cell resistance remains essentially constant. The dominant ohmic losses through the electrolyte are reduced by decreasing the electrode separation and enhancing the ionic conductivity of the electrolyte. The electrolyte and fuel cell electrodes obey Ohm's law. That's why the ohmic losses can be expressed by the equation [5]:

$$
\eta_{\text {ohm }}=i R
$$

We can determine from this equation the resistance of the cell, $\mathrm{R}=0.85 \Omega$.

From the curve $P=f(I)$ we deduced the maximum power, $P \max =2.90 \mathrm{~mW}$.

\section{CONCLUSION}

With this test station, quick reliable and efficient tests and trials are now being made in the laboratory CRTEn to analyze and improve the cell performances. The involvement of virtual instrumentation provides the possibility to add new measurement features. The recorded measurement data can be used in other environments such as Matlab. The operator is thus relieved from the onerous conventional tasks of measurements and calculations. Fast reaction when problems occur is a paramount thing during the operation of the station. Despite having an operational test station, there is still room for improvements such as control of water level inside the humidifiers.

\section{ACKNOWLEDGMENTS}

This work was supported by the Empowering Tunisian Renewable Energy Research Activity (ETRERA): A Project for Europe-Tunisia Cooperation.

We thank also the technicians Sabeur Azzouni, Fehri Krout and Zeineb Abidi for their help to achieve the station test of fuel cell.

\section{REFERENCES.}

[1] S. Sumathi ; P. Surekha,"LabVIEW based Advanced Instrumentation Systems", springer, 728 p, ISBN-10: 3540485007, ISBN-13: 978-3540485001, 2007.

[2] W. Schroder, D. Bevers, de 1-2/98 48-50.

[3] G.Heidek, Micro-computer control for a fuel cell test bench for residential use Journal of Power Sources 127 (2004) 319-324

[4] www.fuelcellstore.com

[5] Fuel cell handbook (sixth edition). EG\&G Technical service. Science Application International Corporation. November 2006. 2-11 